УДК 327

DOI dx.doi.org/10.30970/vir.2018.44.0.7753

\title{
MEDIA INTERPRETATIONS OF HISTORY AND MODERNITY: HOW SELECTED POLISH MEDIA PRESENT POLISH-UKRAINIAN RELATIONS?
}

\author{
Wojciech Cendrowski, Rafał Klepka \\ Pedagogical University of Cracow, \\ 4, Ingardena Str., Kraków, Poland, 30-060, tel. + 481266266 04, \\ e-mail:wrg.cendrowski@gmail.com,rafal.klepka@up.krakow.pl
}

\begin{abstract}
The subject of the article is an attempt at media reconstruction of the image of Polish-Ukrainian relations, with particular emphasis on the role of interpretive journalism in building historical policy and the perception of history by media recipients. The pretext for the analysis is the dispute related to the decision of the Polish minister of foreign affairs about the ban on entering Poland by Volodymyr Viatrovych issued at the beginning of November 2017. This decision caused discourse among Polish politicians and met with wide media resonance. The authors of the presentation analyzed the content of media discourse based on the most opinion-forming materials of Polish TV stations and weekly opinion magazines. The analysis reveals two diverse media pictures and ways of constructing narratives referring to historical relations between Polish and Ukrainian nations. Both images are outlined in the article, as well as their determinants and consequences.
\end{abstract}

Key words: narrations; interpretive journalism; Polish-Ukrainian relations; content analysis.

\section{Introduction}

According to many viewers and readers of media messages about politics, media content should be objective, unbiased and the journalist's opinions should be strictly separated from the fact about events. Some of media recipients prefer the lack of journalistic commentary than combining facts and assessments in one journalistic material. According to this expectations, media coverage of politics would be the most faithful picture of political reality. However, media researchers argue that even factbased journalism and no commentary will never be a full reflection of the world of politics.

In this respect the constructivist position is the most unambiguous. In a farreaching simplification, constructivists prove that reality is not directly accessible to the individual, and human's knowledge of the world is an individual construction of meanings. Observation of the world is therefore its construction and depends on the observer. Referring the above considerations to the opposition of the objectivity and bias of the media message, the issue of constructivism is recommended to look from the outside. The mass media can't be a tool using to reflect reality. Media create reality and this new construction can't be assess in which extend it is objective or biased because the reality is not available for the observer $[4 ; 5 ; 19]$.

(C) Wojciech Cendrowski, Rafał Klepka, 2018 
However, not all media researchers criticize the possibility of building media coverage which reflect the socio-political reality in some way. However, they assume that even a sufficiently high level of journalism professionalism only to a limited extent enables to create an unbiased media coverage, and objectivity is only seemingly possible to achieve. On the one hand, the selection of material or topic presented in the media, the abbreviation of the statement or the presentation of this, and no other quotation from the conversation with the politician, necessarily is an unintentional resignation from objectivity. On the other hand, political actors or mass media may have their own goals in a specific shaping of the created content $[7 ; 14 ; 23]$.

According to many observers, the trend in the way the media informs about politics is clearly evolving. Journalism becomes less descriptive and based on facts, and more and more focused on comments, opinions and interpretations. Brian McNair notes «one of the most frequently noted, and also most criticised aspects of contemporary political journalism is the remarkable expansion in recent years of the commentary form, what I will call the interpretative moment in the news cycle spaces in the public sphere where evaluation of, and opinion about either the substance, the style, the policy content or the process of political affairs replaces the straight reportage of new information» [18, p. 61]. Critics of this trend do not say that commentary is without value in political journalism - only that it has expanded as a proportion of total output beyond what is required or good for rational political decision-making, and at the expense of straightforwardly informative reportage. The researcher has argued «In what is, at one level, an extension of the process versus policy debate, one important aspect of the crisis of public communication is said to be the ascendancy of subjective journalistic interpretation over objective fact-reporting». According McNair normative functions of political news are being undermined by a proliferating commentary industry; a plethora of pundits who, drawing their cultural power from the privileged status of the journalist as licensed truth-teller, increasingly flood the public sphere with speculation and conjecture.

The rise of political commentary was less critically evaluated by Stephen Cushion. $\mathrm{He}$ analyzed the development process of information journalism, in particular the evening television news bulletins, sees a clear departure from the fact-oriented journalism towards the convention of journalistic interventionism. The process that significantly affects this trend is the mediatization of social life, changing the logic of the media. Their role is not just about simply transmitting messages, but also about creating the message and influencing its reception, what is the essence of the discretionary power of journalists and media [2, p. 24].

Interpretive journalism is assessed differently but researchers agree that opinions are increasingly present in media coverage of politics. Brant Houston argued that interpretive trend is connected mainly with the expectations of media recipients who need not only information, but also the key to their understanding. Media massiveness makes them available to everyone, and therefore recipients with different levels of knowledge, experience or orientation, want explanation, not just the naked fact $[8$, p. 2501]. Hence, journalism goes beyond the basic facts of an event or topic to provide context, analysis, and possible consequences. Interpretive journalists must have 
unusual familiarity with and understanding of a subject, and their work involves looking for patterns, motives, and influences that explain what they are reporting.

The most important features of interpretative journalism are:

- emphasize a shift of emphasis related to the five Ws of journalism: What, Where, When, Who and Why, generally speaking, interpretive journalism is conceptualized as entailing a greater emphasis on the 'meaning' of news beyond the facts and statements of sources, and a greater emphasis on the Why of the five Ws;

- disbelief in the notion that it is possible to separate facts from values ratings and opinions about facts;

- the descriptive style places the journalist in the role of an observer and the interpretive style requires the journalist to act also as an analyst;

- comments favor increasing media negativity or cynicism towards politicians and to an increasing focus on the framing of politics as a strategic game;

- interpretation is a kind of empirical discourse, but goes beyond current facts, setting or historical context to speculate on such things as significance, outcomes and motives, while giving opinion refers to journalists exercise of judgment, either normative (what is good or bad) or empirical (what is true or false);

- decline of event-centered reporting;

- a greater emphasis on the journalistic voice, which may include overt commentary, accompanied by, for example, shorter sound bites by politicians [22, p. 145-147].

Researchers involved in the empirical analysis of the interpretative journalism frequently use content analysis to determine how much of the media materials in a given period or on a given subject, tends to assess the facts, and not only to their presentation. Many cases, most notably in Thomas E. Patterson's analysis, empirically proved that facts and interpretations have become increasingly intermingled in contemporary journalism. The extent to which this interpretive form of reporting has taken over newspaper coverage is evident in the New York Times. Between 1960 and 1992, the proportion of interpretive reports on its front page increased tenfold, from 8 percent to 80 percent [21, p. 102]. According to him, the interpretive style empowers journalists by giving them more control over the news message. Whereas descriptive reporting is driven by the facts, the interpretive form is driven by the theme around which the story is built.

Building stories based on interpretive materials on politics is another link in the evolution of political journalism. The changes that led from the concentration of facts to the growth of the role of interpretation are progressing, transforming the interpretations into ready narratives. The direction of these changes is illustrated in the figure below. 
Wojciech Cendrowski, Rafał Klepka

Figure 1. Trends in the manner of presenting political issues in contemporary media. - Source: own study

At first glance, it seems that the narratives are characteristic for literature, not for journalism or politics [1, p. 673-676]. However, George Lakoff argued that metaphorical thinking results from human biological processes and is the most typical way of human perception of the world. Also in relation to politics, we use metaphors, scripts, associations and narratives. This simplifies the perception of reality, thanks to which information is perceived by the individual without the need to constantly analyze their sense and rationality, but on the principle of general adjustment, so that together they constitute a uniform narrative $[16 ; 17]$.

Narratives should be understood as coherent, seemingly matching interpretations, which are often products of culture and ideology [6]. Narratives construct collective ideas, explain history, fill the knowledge gap, build myths, become the content of politics in the era of an uninformed voter, but also allow to distinguish, leading to polarization [24]. Formerly, the narrative style of journalism was characteristic of the boulevard press. The material then began with an anecdote, which then led to the presentation of the history of the life of celebrities or ordinary people [20]. At present, narratives are more and more often appearing in television news programs and newspapers, allowing recipients to receive political reality in a simplified way, but giving a sense of conviction that the elements of this reality match each other.

Narratives connected with relations between neighboring states may give rise to divisions and lead to disputes. The aim of the article is an attempt at media reconstruction of the image of Polish-Ukrainian relations, with particular emphasis on the role of interpretive journalism in building historical policy and the perception of history by media recipients. The pretext for the analysis is the dispute related to the decision of the Polish minister of foreign affairs about the ban on entering Poland by Volodymyr Viatrovych issued at the beginning of November 2017. This decision caused discourse among Polish politicians and met with wide media resonance.

\section{Methodology}

In the presented study, the authors use media content analysis. According to Klaus Krippendorff, this method is potentially one of the most important research techniques in the social sciences. The content analyst views data as representations not of physical events but of texts, images, and expressions that are created to be seen, read, interpreted, and acted on for their meanings, and must therefore be analyzed with such uses in mind [15, p. 11]. Content analysis is a method of studying and analyzing communication in a systematic, objective, and quantitative manner for the purpose of measuring variables [13].

For the purposes of analysis of the Polish-Ukrainian relations the following two evening television news bulletins and three nationwide weekly papers were selected: «Wiadomości» TVP, «Fakty» TVN, «Polityka», «Newsweek» and «Do Rzeczy». This news bulletins and weekly papers were chosen due to their established position on the market and due to the fact that, in the recipients' opinion, they represent different political options («Fakty» TVN, «Polityka» and «Newsweek» is associated with 
liberal and centre-left views, whereas «Wiadomości» TVP and «Do Rzeczy» - with the right-wing ones). In addition, «Wiadomości» program is flagship news bulletin in public television and «Fakty» is broadcasted by commercial one. It is also very important that news bulletins and weekly papers are among the most widely-watch and read titles on Polish market. The analysis covered all news bulletins and all copies of the selected weekly papers titles, issued in the period from $2 \mathrm{dr}$ until 15 th November 2017.

The analysis was preceded by the preparation of categorization key which was adjusted to the needs of the study. The research covered all materials which refer to decision of the Polish minister of foreign affairs about the ban on entering Poland by Volodymyr Viatrovych. However, this issue was pretext to build wide variety of opinion, speculation, interpretation and narrations connected with past, present and future of Polish-Ukrainian relations.

\section{Results}

At the first step, headlines in the television news bulletin was analyzed. In «Wiadomości» TVP headlines were unfavorable to Ukraine: «A Harder course towards Ukraine», «Ukraine must account for the Volyn crime», «Ukrainians relativize history». The same facts and the same event were described in «Fakty» TVN completely different: «The dispute between Poland and Kiev in connection with the UPA monument», «Poland has tense relations with Germany and Ukraine», «Tense relations with Ukraine. Waszczykowski prefers to talk about a good change», «Accusations and omitted anniversary. Crisis in Polish-Ukrainian relations».

On the basis of headings in TV news bulletin in public broadcaster and the content of the news, the contexts of Polish-Ukrainian relations was captured. In «Wiadomości» TVP only Polish government's point of view was presented. News program noted that Ukraine is doubly guilty: in the past for the UPA, currently for searching for its own historical identity. Some news indicated the openness of the Polish government and the lack of readiness for talks on the part of Ukraine. "Wiadomości" tried to explain what Ukraine should do, to change relations with Poland.

In private television TVN news program «Fakty» tried to show both Polish point of view, but also Ukrainian one. In «Fakty» the ambiguity of the situation and the lack of unambiguous interpretation of history and present events was emphased. However, in «Fakty» as the most important chalange was necessity of build the future accented. «Fakty» tried to indicate the way for Polish-Ukrainian raltions by formulating a postulate regarding the value of dialogue. «Fakty» also pointed to the confrontational policy of the Polish government towards all its neighbours countries.

Pictures presented in both news bulletins played completely different role. In «Wiadomości» TVP news there was drastic images of bones excavated during archaeological work. In «Fakty» TVN more subdued, archival recordings of escaping civilian population was presented. 


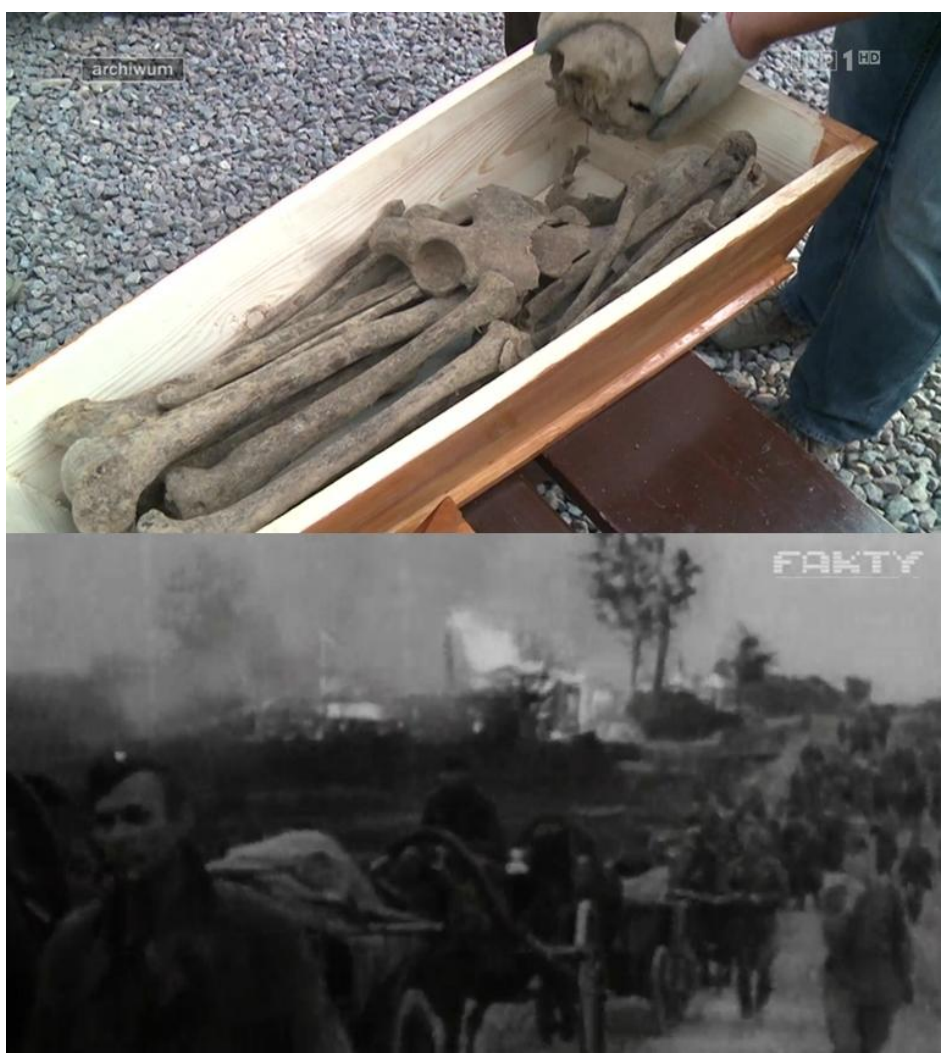

Figure 2 Pictures in «Wiadomości» TVP and «Fakty» TVN illustrating Polish-

Ukrainian events from the past-Source: TV screenshot

The role of experts and commentators in both programs was different. In «Wiadomości» TVP, ruling politicians spoke out, publicists were positive to the government. In «Fakty» TVN, the selection of experts was more diversified: statements from various scientific centers, experts, politicians of the ruling party and also opposition parties was presented.

The second plane in which Polish-Ukrainian relations bounced back was the press. «Newsweek» has published a series of articles under titles such as: «History spoofer» (about ruling party Law and Justice), «Quarrels between Poland and Ukraine? Putin rubbing his hands», «Crisis in the Ministry of Foreign Affairs. Relations with Germany and Ukraine», «Polish-Ukrainian relations the worst in years. It is not good with Germany either. Opposition: The PiS government has only improved relations with Belarus».

In weekly papers «Polityka» headlines express criticism of the Polish government and its policy: «Ząb za zub. Unthinking symmetry in Polish foreign policy has just led our relations with Ukrainians to the worst state in the history of both countries», «The Polish-Ukrainian conflict is growing. Because of the so-called PiS diplomacy».

In right-wing weekly parer «Do Rzeczy» more conservative views was presented. announced by the titles: «Criminals' cult in Ukraine: The fiasco of Polish Eastern 
policy», «Prof. Żaryn: Ukraine does not want to belong to Roman civilization», «Ukrainian nationalists and the Polish cause», «The Cold war about the Bandera».

«Polityka» and «Newsweek» used content and headings of articles to build narrative around Polish-Ukrainian relations. Both newspapers showed that Polish government leads a wrong policies, departed from politics of former president Lech Kaczyński towards a confrontation policy. Some of the article's contexts were depressive-dramatic indicating crisis in the Ministry of Foreign Affairs, lack of skills to build alliances with neighboring states. In magazines there was also attempts to draw attention to the fact that common, Polish-Ukrainian, history was important, difficult and ambiguous, but the most important must be focus on the future relation.

In right-wing «Do Rzeczy» the rhetoric of ruling polish party was presented. Weekly paper argued that the policy of former governments was wrong - the past must be settled. Ukraine was presented as a state developing anti-Polish policy, where citizens are barbarians who do not fit into Europe. In «Do Rzeczy» pictures of protests of extreme groups were published as evidence of the cult of Bandera in Ukraine.

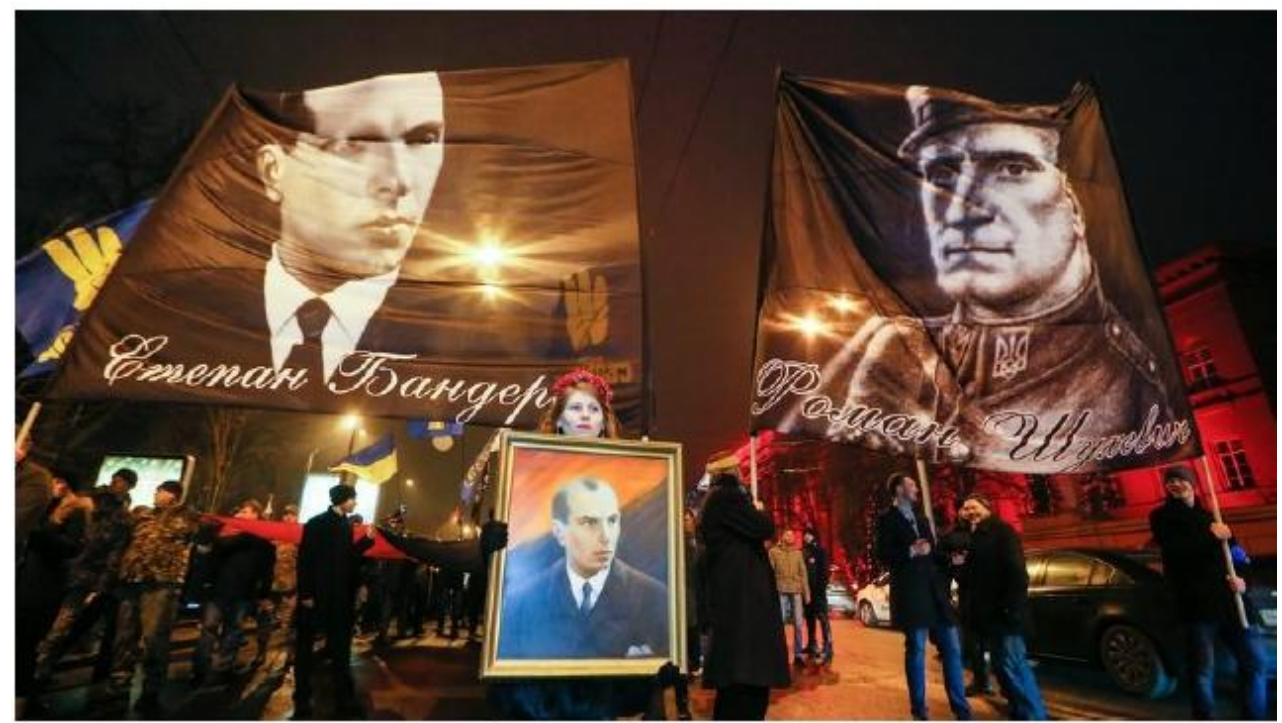

Figure 3 Pictures in «Do Rzeczy» illustrating the manifestation in Ukraine Source: TV screenshot

\section{Discussion}

Analyzed media created two different narrations of Polish-Ukrainian relations. In «Wiadomości» TVP and weekly paper «Do rzeczy» narrative focused on conflict, and was close to the vision of ruling party, critical towards Ukraine, positive towards Polish politics. On the other hand - in «Fakty» TVN and weeklies «Newseek» and «Polityka» there was completely different narration. This narrations emphasized the necessity of a peaceful resolution of the Polish-Ukrainian dispute, was critical of the 
ruling party and current Polish politics. This narration suggested that building the future is more important than quarrel about a difficult history.

The existence of two opposing narratives about Polish-Ukrainian relations proves the huge role of interpretive journalism and its ability to create narrative. These simplified visions of the world help to understand political processes, but they do not replace knowledge, discussions, do not bring people closer to rationality.

The existence of such highly polarized media seems to be in some extent a consequence of the strong social polarization that has occurred in Poland at least since 2010, if not since 2005 [9-12]. By the way, the concept of media market foxification seems to be remarkable, which assumes that the pattern of trends in the United States, also in Poland, is shaping a new pattern of politically engaged media [3]. According to this concept, the external pluralism of the media is natural, but each television stations and magazines almost directly indicate support for selected party. The media, on the other hand, have an increasingly identity character, which means that the recipients don't treat the media as a source of knowledge about politics. Viewers and readers definitely want to get confirmation of their opinions and watch or read the content that confirms their political views.

The media contributes greatly to the understanding of the relations between neighboring nations. This is why content analysis of media on Polish-Ukrainian relations is of great value. The results of such analyzes will allow to assess whether and in which direction the manner of presenting information on Ukrainians and Poles, the policy of both states and relations between states evolves.

\section{BIBLIOGRAPHY}

1. Browning L. Narrative and Narratology. In: Littlejohn SW, Foss KA (eds.). Encyclopedia of Communication Theory. Los Angeles, London, New Delhi, Singapore, Washington DC 2009.

2. Cushion S. News and Politics: The Rise of Live and Interpretive Journalism. London, New York 2015

3. Cushion S, Lewis J. Towards a 'Foxification' of 24-hour news channels in Britain?: An analysis of market-driven and publicly funded news coverage. Journalism 2009; 10.

4. Fleischer M. Media w perspektywie konstruktywizmu. 2K - Kultura i Komunikacja 2005.

5. Fleischer M. Zarys ogólnej teorii komunikacji. In: Habrajska G (ed.). Mechanizmy perswazji i manipulacji. Łask: Leksem, 2007.

6. Fulton $H$. Introduction: the power of narrative. In: Fulton H., Huisman R., Murphet J., Dunn A. (eds.). Narrative and Media. Melbourne 2006.

7. Hopmann DN, Van Aelst P, Legnante G. Political balance in the news: A review of concepts, operationalizations and key findings. Journalism 2011; 13.

8. Houston B. Interpretive Journalism. In: Donsbach W (ed.). The International Encyclopedia of Communication. Malden, Oxford, Carlton 2008.

9. Klepka R. Wizje państwa w programach wyborczych z 2005 r. Platformy Obywatelskiej oraz Prawa i Sprawiedliwości. Chorzowskie Studia Polityczne 2008.

10. Klepka $R$. Czynniki dynamizujące zmiany polskich elit politycznych po roku 1989. Chorzowskie Studia Polityczne 2009.

11. Klepka R. Geneza i instytucjonalizacja polskich elit politycznych po 1989 roku. In: Wróbel S. (ed.). Transformacja ustrojowa w Europie Środkowo-Wschodniej. Płaszczyzny - wymiary - kierunki. Toruń 2010 . 
12. Klepka R. Podziały elit politycznych jako kryterium periodyzacji okresu III RP. In: Sielski J., Mizgalski J., Hajduk J. (eds.). Polska między przeszłością a przyszłością. Księga jubileuszowa dedykowana Profesorowi dr. hab. Janowi Walczakowi. Częstochowa 2013

13. Klepka $R$. Analiza zawartości mediów: dlaczego i do czego można ją wykorzystać w nauce o bezpieczeństwie i politologii? Annales Universitatis Paedagogicae Cracoviensis Studia de Securitate Educatione Civili 2016; VI.

14. Klepka R. Obrazy polityki w mediach: podstawowe uwarunkowania. In: Klepka R. (ed.). Medialne obrazy świata. Wybrane problemy społeczno-polityczne w mediach. Kraków 2018.

15. Krippendorff $K$. Content Analysis: An Introduction to Its Methodology. Thousand Oaks, London, New Delhi 2004.

16. Lakoff G. The Political Mind: A Cognitive Scientist's Guide to Your Brain and Its Politics. New York 2009.

17. Lakoff G, Johnson M. Metaphors We Live By. London 1980.

18. McNair B. Journalism and Democracy: An Evaluation of the Political Public Sphere. London, New York 2012

19. Michalczyk S. Demokracja medialna. Toruń 2010

20. Nerone J. Narrative News Story. In: Donsbach W (ed.). The Concise Encyclopedia of Communication. Malden, Oxford, Chichester 2015

21. Patterson TE. Bad News, Bad Governance. The Annals of the American Academy of Political and Social Science 1996.

22. Salgado S, Strömbäck J. Interpretive journalism: A review of concepts, operationalizations and key findings. Journalism 2012; 13.

23. Toggle CA. The bias toward finding bias in television news. Communication Reports 1998; 11 .

24. Wasiuta $O$. Mit jako fenomen współczesnej polityki. Warmińsko Mazurski Kwartalnik Nauk Nauki Społeczne 2012; 1 .

Стаття надійшла до редколегї 10.06.2018

Прийнята до друку 01.09.2018

\title{
МЕДІА-ІНТЕРПРЕТАЩІЯ ІСТОРЇ̈ І СУЧАСНОСТІ: ЯК ПОЛЬСЬКІ ЗМІ ПРЕДСТАВЛЯЮТЬ ПОЛЬСЬКО-УКРАЇНСЬКІ ВІДНОСИНИ?
}

\section{Войцех Цендровський, Рафал Клепка}

\author{
Педагогічний університет ім. Наиіональної Комісії з Питань Освіти, \\ вул. Інгардена, 4, м. Краків, Польща, 30-060, тел.+48 1266266 04, \\ e-mail:wrg.cendrowski@gmail.com,rafal.klepka@up.kraków.pl
}

Основою статті $є$ спроба ЗМІ відновлення зображення польсько-українських відносин, 3 особливим врахуванням ролі інтерпретаційної журналістики у будуванні історичної політики і сприйняття історії через користувачів ЗМІ. Причиною аналізу стала суперечка, пов'язана 3 рішенням польського міністра закордонних справ про заборону в‘їзду в Польщу Володимира В'ятровича, яка була видана на початку листопада 2017 року. Таке рішення викликало дискурс серед польських політиків. Головні учасники проаналізували зміст медіа-дискурсу, на підставі матеріалів, взятих 3 найвпливовіших польських телевізійних станцій і щотижневих публікацій. В результаті аналізу виникло, що ЗМІ по різному представляють інформацію, яка стосується історичних відносин між Польщею та Україною. В рефераті будуть зображені два способи представлення інформації, а також їх зміст і наслідки.

Ключові слова: інтерпретивна журналістика; польсько-українські відносини; аналіз змісту. 